\title{
IWRM and the environment: A view on their interaction and examples where IWRM led to better environmental management in developing countries"
}

\author{
Kees Leendertse ${ }^{1 *}$, Steve Mitchell ${ }^{2}$ and Joakim Harlin ${ }^{3}$ \\ ${ }^{1}$ Cap-Net / UNDP International Network for Capacity Building in Sustainable Water Management; Marumati Building, \\ 491 18th Ave, Rietfontein, Pretoria 0084, South Africa \\ ${ }^{2}$ Water Research Commission, Private Bag 03, Gezina, South Africa \\ ${ }^{3}$ United Nations Development Programme, SIWI, Stockholm, Sweden
}

\begin{abstract}
This paper investigates the interaction between water resources management and the environment. It argues that an integrated, holistic approach to water management is beneficial for the environment but also that environmental concerns are not to be ignored for integrated water management to be effective. To this purpose the paper introduces the interactions between different water uses and why it is important to address these interactions for sustainable water resources management. It explains how the environment is being effected by the use of water by other sectors, and the benefits and implications of an integrated management system for the environment. Illustrated by several practical cases in Asia, Southern Africa and small island developing states, the paper makes a strong case for IWRM to be an effective approach for sustainable management at river basin level. It also demonstrates that stakeholder engagement form the start. and the process being driven by local interests and addressing real needs are elements of IWRM without which it will not work. The paper argues that addressing environmental is essential for sustainable use of water resources, and that strong political support and institutional backing is required for IWRM to be successful.
\end{abstract}

Keywords: integrated water resources management, environment, river basins, interaction, water uses, benefits, implications, institutional, legislation, instruments, stakeholder participation, local management.

\section{Introduction}

The environment has special functions when it comes to sustainable water management. It is used to purify and store water and has a role in the hydrological cycle. Apart from the benefits of environmental management for sustainable water use, there are also environmental benefits from proper management of water resources, such as protecting upper catchments, pollution control, safeguarding common resources on which communities depend, or an ecosystem approach to water management. However, the environment is often least considered when water management policies and plans are being developed and more often neglected when it comes to implementation. This paper addresses these issues and draws lessons from past experience to enhance practices in future.

The case is made for the use of integrated water management methods and techniques to the benefit of the environment and is supported by examples. The paper first looks at interactions between water management and the environment and continues with consideration of the environment in water policy development. It then addresses water management instruments as tools to protect the environment and finally argues that application

Revised version. Originally presented at the International Conference on Integrated Water Resource Management (IWRM) entitled: Lessons from Implementation in Developing Countries which took place from 10 to 12 March 2008 in Cape Town, South Africa, at the Cape Town International Convention Centre.

* To whom all correspondence should be addressed.

+2712 330 9074; fax: +2712331 4860

e-mail: kees.leendertse@cap-net.org of an integrated water resource management (IWRM) approach leads to better environmental management.

\section{Interaction between IWRM and the environment}

In order to establish whether new management practices under IWRM are beneficial to the protection of the environment, the interaction between water and the environment, and between the environment and other water use sectors, have to be analysed. Questions to ask are:

- How does the environment use water?

- Why is the environment important to water management?

- How does the environment interact with other water use sectors?

- How does the environment benefit from IWRM?

- What are the implications for change?

\section{How does the environment use water?}

The relationship between the environment and water is best demonstrated by the way they interact. Ecosystems need water to maintain their functioning: plants evaporate and transpire water; animals drink water; fish and amphibians need water to live in (Cap-Net, 2003). The composition of an ecosystem is to a large extent determined by the presence and accessibility to water.

Water is used by upper-watershed ecosystems, like forests, shrublands and woodlands downstream, wetlands, floodplains, and mangroves need freshwater inputs. This water is used to maintain a (semi)-natural dynamic, often of a seasonal nature. To prevent degradation and destruction of ecosystems, it is important to have enough water of the appropriate quality and with the correct seasonal variability. 


\section{Why is the environment important to water management?}

Ecosystems provide goods and services (functions) that benefit people and their livelihoods. These benefits are often not fully recognised in planning and managing water resources. The total benefits are estimated to be USD $8.8 \mathrm{bn}$./yr (IUCN, 2000). The Millennium Ecosystem Assessment reported in 2005 that the value of wetlands is underestimated, and Costanza et al. (1997) estimate that the global economic importance of wetlands could be as high as nearly USD 5 trillion annually.

Natural ecosystems provide many services to humankind that are often neglected in planning and decision making:

- Regulation functions: The capacity of natural and semi-natural ecosystems to regulate essential ecological processes and life support systems;

- Habitat functions: Providing refuges for wild plants and animals (and native people) in order to maintain biological and genetic diversity;

- Production functions: Resources provided by natural and semi-natural ecosystems;

- Aesthetic/recreational functions: Providing opportunities for reflection, spiritual enrichment and cognitive development.

The regulatory functions of the environment manifest themselves in various ways, such as in maintenance of biogeochemical cycling, climate and water regulations, soil retention, water purification, etc. Besides providing refuge, the habitat function is also clear in providing nursery habitats for many species. The production functions are most clear in food and energy production but also more indirect in the production of fertilisers, medicinal and genetic resources, as well as ornamental resources. Additionally to the estimate mentioned above, the annual value is agricultural products alone in 2001 was more than USD 950 bn. (Millennium Ecosystem Assessment, 2005). For recreational and cultural, spiritual or religious activities, the environment is of essential importance

\section{How is the environment affected by water use in other sectors?}

The environment needs water to sustain itself but in the water allocation decision-making process the needs of the environment are often neglected. If too much water is allocated to other sectors, the impacts on ecosystems can be devastating.

The agricultural sector is the largest user of water and impacts most heavily on ecosystems' 'water share'. Abstraction of water for agriculture is leading to dried-up rivers, falling groundwater tables, salinised soil and polluted waterways. If not sufficiently treated, pollution from urban water uses damages downstream ecosystems. The treatment of effluents is often costly and, especially in developing countries, not considered a high priority. When consideration is given to the value of ecosystems, effluent recycling and reuse are often seen to be cost-effective conservation measures. Hydropower installations affect downstream ecosystems by changing the water and sediment regime and blocking migratory movements of fish and other aquatic resources. Sometimes reservoirs have provided new habitats for animals and investments have been made in environmental protection upstream. Combining considerations of power generation, flood control and ecosystem protection can mean that new operational rules need to be developed for reservoir releases. Industry often has substantial impacts on ecosystems downstream through water use and pollution. Transfer of recycling technologies to developing countries could help to pre-empt ecosystem damage from industrial development.

The environment is a competitor to other sectors because water allocated to ecosystem protection is not available for other uses. It is true to say that a proportion of the total water available needs to be assigned to ecosystems, but the synergies with other uses can also boost the total resource by encouraging multiple use and reuse. The costs of not assigning water to ecosystem protection is higher than the loss other sectors may incur by such allocation decisions (Millennium Ecosystem Assessment, 2005). Ecosystems maintained in a healthy state can provide good quality water that can be used by any other user. Clean rivers, nonpolluted groundwater sources and fresh mountain springs are easily disrupted by inappropriate water and land use.

\section{Benefits of IWRM to the environmental sector}

Ecosystems can benefit from applying an integrated approach to water management by giving environmental needs a voice in the water allocation debate. Before the introduction of IWRM these needs are often not represented at the negotiating table where allocation decisions are made or in the legal frameworks defining allocatable water. IWRM can assist the sector by raising awareness among other users of the needs of ecosystems and the benefits these generate for them. Often these are undervalued and not incorporated into planning and decision-making.

The ecosystem approach provides a new framework for IWRM that focuses more attention on a system approach to water management. It provides an alternative to a sub-sector competition perspective, with more emphasis on maintaining the underlying ecosystem as a factor that can join stakeholders in developing a shared view and joint action. Such an approach to water management focuses on several levels of intervention such as protecting upper catchments, pollution control and environmental flows

Most importantly, applying the IWRM approach can bring together communities, industrialists, water managers and opinion formers (teachers, religious leaders, media representatives) in a common cause to achieve sustainability by conserving both water and ecosystems.

Of all the sectors, the environment is probably the one with most to gain from implementation of IWRM principles. The environment is suffering the consequences of water scarcity and poor awareness because, if considered at all in the allocation process, it is usually given low priority. The desire for an IWRM approach is therefore very strong in the environment sector, but there are some stumbling blocks to be overcome such as: lack of awareness of the contribution of the environment to the economy and social wellbeing, political will to conserve the environment, and this results in the lack of human and financial resources being allocated to the environment

\section{Implications for change within the environmen- tal sector: Legal, institutional, human resources}

A major requirement of water sector reform is to provide recognition of ecosystem needs alongside the demands of domestic, industrial and agricultural water users. In many countries, that involves significant strengthening of the status, human and financial resources and political representation of environment agencies, particularly in the context of IWRM at river basin level. National legislation often needs to be harmonised and strengthened to include an environmental perspective into 
water management and other relevant sectoral policies and legal arrangements. At present many conflicting arrangements exist.

Water departments need to function more and more as brokers between various other departments and stakeholders, rather than stand-alone units. They will have a major role in facilitating negotiations between various water users. There is also an important regulation and monitoring function in relation to environmental standards. Participatory decision-making is a crucial part of IWRM, but it has to be in a framework that protects common interest from self interest. Substantive capacity building in facilitation, mediation, negotiation and surveillance is required. Usually staff are not well equipped to take on these responsibilities as they require knowledge and skills beyond those of the disciplines dominating the water sector.

\section{Is the environment considered in water policies development; are institutional arrangements made and management instruments used?}

The Dublin Principles and the Rio Declaration (1992) both recognise that environmental sustainability is central to quality of life and sustainable development. These principles form the basis of IWRM (GWP, 1999) and have guided the development of policies and legislation on water resource management in many countries. Institutional arrangements may vary from country to country depending on the specific conditions of the country, but they are designed to promote the implementation of IWRM principles. They all, however, need to address two areas to succeed. These are the creation of an organisational framework with the correct functions to address the needs of the particular situation and ensuring that there is sufficient capacity within the organisational framework to administer the management instruments properly.

The primary functions to be performed are the allocation of resources, the monitoring of performance and pollution control. Each of these three functions is integral to IWRM and has a component that addresses environmental sustainability. The control of pollution is crucial if the environment is to deliver the full suite of services expected from it. Monitoring of surface water resources includes both the quality as well as the quantity (both flow and timing) of the resource. When considering the allocation of the resource, the principles of IWRM recognise the rights of the environment to receive an allocation. This allocation is expressed in terms of environmental water requirements. The recognition of environmental water requirements, which are now being considered by many countries, is an aspect of resource allocation which has given the environment a voice. The awareness created by the establishment of environmental flows has raised the profile of the need for environmental sustainability and the services that the environment provides. The extent of the suite of services provided by the environment is largely governed by the water (both quality and quantity) allocated to the environment

In South Africa, for instance, the enabling environment for IWRM is provided by resource directed measures (RDM) within the National Water Act. The RDM covers the classification of water resources, the Reserve (consisting of two components, the basic human needs reserve and the ecological reserve) and setting of resource quality objectives (RQOs). Institutional arrangements include the establishment of catchment management agencies (CMAs) which work at the river basin level. The CMAs have, amongst others, the responsibility for administering the management instruments aimed specifically at environmental sustainability. The environmental water requirements (known as the 'ecological Reserve') form an integral part in the process of classifying water resources. The resource classification system provides the framework for classifying water resources and setting RQOs. This includes the environmental water requirements which are set in congruence with the RQOs for a particular resource. Pollution is managed through sourcedirected controls and a waste-discharge charge system which is based on the principle of the 'polluter pays' (Belcher, 2008).

Experience from Uganda indicates that it is not enough to have good policies and legislation. These have to be backed up by the political will to implement them, which includes effective enforcement of compliance. There also needs to be a good framework for implementation which must have a strong public awareness component. Where these are lacking, implementation becomes very difficult (Tindimugaya, 2008).

In countries where IWRM-based institutions are replacing traditional common property resource institutions, the political will to apply the IWRM approach fully is critically important. In situations where this is absent, the route of legal pluralism is followed. What this means is that resource use is governed by a mix of national policy and traditional property access rights. While this may be a necessary route to allow resource use to continue in the absence of clear policy implementation (Pollard and Cousins, 2008), it is also open to abuse. In the Inner Niger Delta, Beeler (2006) recorded that the traditional institutions which have ruled the use of the common pool resource (CPR) of the fisheries of the Delta had been partly replaced by government policy which has not been effectively implemented. The elaborate system governing the access to and use of natural resources, which ensured families access to fishing rights through traditional agreements and for the payment of a 'levy' of one third of their catch, was well adapted to local conditions and able to assure the conservation of the ecosystem. However, in post-colonial times the traditional leadership has been eroded to the point where the CPR is still under the traditional leadership, albeit illegally, but the traditional leadership now sells the fishing rights to the wealthy, forcing the families who previously had traditional rights to fish in marginal areas. The result is that the resource is under pressure and is no longer being managed sustainably. In order to avoid situations such as this from developing, it is essential that the advancement of IWRM is supported by strong political will.

\section{Water management instruments to protect the environment}

Several water management instruments are at the disposal of managers addressing environmental concerns related to ecosystems. Cases in Malaysia and South Africa have shown how differently some issues are being interpreted and which instruments are applied. The flexibility with which IWRM is being interpreted serves the process to fit the country's specific needs.

In the case of Malaysia the emphasis of management has been on legal instruments and institutional arrangements to protect environment from external factors threatening the ecosystem integrity (Zakaria, 2008). Some of these externalities have been identified as:

- Population growth

- Increased and diversified land use

- Deforestation

- Pollution and water quality

- Flood mitigation

- Catchment erosion

- Forest fires and drained peat lands. 
Solutions at the federal level were offered through central development planning, and monitoring and enforcement. Federal environmental and water agencies were created to implement policies developed. Civil society participation was encouraged through the involvement of NGOs.

States in Malaysia have a high level of autonomy and seemingly unlimited resources with their own policies and objectives. This may hamper the management of a river basin shared by different states such as the case of the Langat River basin. However, sources are allocated by federal government and raised through levying of land and corporate taxes. The federal agencies mentioned have subsidiaries at the state level who mainly work with local and provincial authorities, and village heads.

At the Langat River basin level, the main issues are caused by:

- Lack of integrated approach to planning on the basis of river basins

- Lack of coordination or centralised authority

- Lack of social development and awareness

- Lack of regulations and awareness

- Poor data and information sharing among agencies and stakeholders.

Solutions are sought in institutional reform in the basin and integrated river basin management planning. New management regimes should ensure the development of partnerships among stakeholders and their participation in management. A river basin agency is set up to guide the process of management based on a sound scientific basis, in which capacity building and data sharing are key elements. The implementation of the IRBM plan can lead to the following major outputs:

- Reduction of man-caused land degradation and soil erosion

- Arresting habitat loss/ degradation and rehabilitate, conserving and enhancing bio-diversity

- Prevention of water quality degradation and improvement of water quality

- Regulation of water demand and development of new water supply sources

- Mitigation of severity of floods and reduction of frequency of flooding

- Sustainable use and management of river system and river corridors

- Initiation, development and implementation of an effective governance and management support system.

Although the intended outcomes are largely the same as in the case of the Langat River basin management in Malaysia, addressing the water environmental needs in South Africa has been quite different (Belcher, 2008). The focus of the process in South Africa has been strongly on organisational, institutional and legal aspects and not so much on implementation.

The organisational framework established concerns central government departments, CMAs, water user associations (WUAs) and local authorities, among which different levels of tasks have been allocated; typical of a quasi-federal system with local, regional and national competence. The management responsibility is at departmental level (with the Departments of Environmental Affairs and Tourism/DEAT and Water Affairs and Forestry/DWAF each with separate mandates), whereas the CMA and WUAs have the de facto responsibility to implement environmental policies.

The legal and regulatory framework is governed by a series of national environmental and water acts relatively recently established (the National Water Act (NWA), Act 36 of 1998).
The National Water Resource Strategy (2004) gives effect to the NWA. Under previous legislation, the DWAF regional offices were responsible for the management of the water resource, but these will be replaced by the river basin organisations. The Constitution is the overarching enabler as it stipulates that "Everyone has a right to an environment that is not harmful to their health or well-being and to have the environment protected for the benefit of present and future generations" (The Constitution of South Africa, 1996). Institutional capacities are to a large extent determined by governmental structures with private sector and civil society participation.

An extensive assessment and monitoring system has been developed and established under the National Water Act and the National Environmental Management Act. National, provincial and catchment/local plans and strategies have been or are being developed. The challenge now lies in the implementation of these plans and obstacles that may have to be faced. In implementation, some issues that need to be considered are:

- Integration of land and water use management

- Awareness creation. and development of a common understanding and vision

- The incorporation of environmental aspects within water resource management

- The use of economic instruments

- Monitoring and enforcement

- Allocation of adequate resources.

Analysing the two cases, the conclusion is that in Malaysia, although centrally organised, the focus has been on basin management and implementable action, whereas in South Africa the emphasis has been on setting up regulatory and organisational structures first before implementing integrated management. In both cases the suite of water management instruments seems to be beneficial for environmental concerns although the integration of water and environment is not always clearly established.

\section{Does the implementation of IWRM lead to better environmental management: Case studies}

We have shown that integrated water resource management plays an important role in the overall protection and sustainable management of the environment, and that the needs of the environment are taken into account in the development of policy. However, will the environment benefit from these policies? To address this, we present a series of case studies which are then examined from defined criteria and certain conclusions are drawn from these.

Pungwe River basin, Zimbabwe-Mozambique, Southern Africa. An enabling environment was established in both countries through policy and legislation. Mozambique, through its Department of Water Affairs, established its National Water Resource Strategy in 2004, and the initiative in Zimbabwe was underpinned by the Zimbabwe Water Act (1998) and the Zimbabwe National Water Authority Act and Statutory Instrument of 2000. River basin organisations (RBO) were established in both countries in order to give effect to the policies and legislation in the Pungwe River basin.

Since the RBOs came into existence action has been taken on several environmental issues. Databases and a monograph have been prepared on water quality and sediment transport, pollution, conservation areas and environmental flow requirements. Pollution permitting, monitoring and enforcement have been introduced and this has led to the mitigation of illegal 
gold panning with mercury in upper parts of the river. In addition, detailed climate change modelling which links global and regional models to local hydrology has been undertaken. This has enabled the assessment of impacts and forms the basis for vulnerability assessments and adaptation strategy development. The Joint Integrated Water Resource Management Strategy for the Pungwe River basin has been able to materialise the vision of a broad and sustainable socio-economic development without environmental harm (www.pungweriver.net).

China - Provincial level: Liao River Basin Management Rapid development in the Liao River Basin, China, has resulted in water shortages and severe water pollution. Untreated urban wastewater was being discharged into streams and in some cases it infiltrated the aquifers. In addition, deforestation took place in the upper parts of the catchments. The action taken was to establish an institutional framework under which an IWRM Planning Project was developed and implemented.

The implementation of this IWRM project led to substantial improvements in the Liao River Basin. Pollution loads have been reduced by $60 \%$ and quality of river water considerably improved, upstream-downstream conflicts over water have been reduced, groundwater pollution has been reduced and deforestation practices have been halted. In addition, drinking water within the basin has been safeguarded and ecosystems in several river stretches have been restored. The project has also achieved success in raising public awareness of demand management and pollution risks. (EU Liaoning Integrated Environmental Program 2008).

The National IWRM and WE Plan for improved management of scarce water resources and pollution control in Kazakhstan. There are many water-ecological problems serving as obstacles, of which the most acute ones are growing water deficit; pollution of open and underground waters; enormous over-norm water losses; exacerbation of the problem of quality drinking water supply to population; problems of interstate water apportioning; and deterioration of the technical state of the dams, waterworks facilities and other installations. The situation with water management is tense throughout the territory of the republic and the environmental ill-being has overtaken all major river basins of the country.

The recognition by Kazakhstan that it was necessary to improve its efficiency of water use led to the generation of a New Water Code for IWRM in 2003. This was followed in 2004 by the start of the project for the National IWRM and WE Plan for Kazakhstan. This plan was completed in 2005 and in the following year the water and environmental laws were harmonised. For the implementation of the IWRM Plan, river basin organisations, namely basin councils are being created. In the sense of territorial division, the basin councils have been created in 8 hydrographic basins of Kazakhstan as well as in separate water objects to increase the involvement of interested parties in water resource management. This initiative has led to better water allocation, including water allocated to environmental flows. It has also led to water quality issues being addressed more effectively and an early outworking of this has been the initiation of effective pollution control (Nikolayenko and Kenshimov, 2008)

Chile undertook its Water Code Reform in 2005 to establish a more stable balance between the public interest and the rights of private individuals and among social and productive demands and environmental considerations. Water resources are now governed through a strong system of institutions, laws, and rules that are closely related to the national development strategy. This new water law obliges the General Directorate of Water Resources to consider environmental aspects in the process of establishing new water rights, especially in terms of environmental water requirements and sustainable aquifer management. Working in water-scarce areas has increased the prices of water rights and forced the mining sector to increase the efficiency of its water use threefold over the last 20 years, while water use in wood pulp production has fallen by $70 \% / t$ produced. Macro-economic policies to improve cost recovery have caused household water consumption to fall by $10 \%$, in reaction to a $38 \%$ increase in domestic water supply. Some sectors (such as mining, agriculture and wood pulp production) have gone beyond national requirements and agreed to clean production programs accepted globally. The percentage of sewage treated in Chile leapt from $17 \%$ in 1997 to $81 \%$ in 2005, and by 2010 almost all of the country's sewage is likely to be treated (GWP Technical Committee, 2006).

Cap-Net has conducted a review of four river basin organisations (Mahaweli in Sri Lanka, Tana Basin in Kenya, LermaChapla-Santiago in Mexico, and Sungai Langat in Malaysia, 2008) (Cap-Net, 2008). The RBOs reviewed were the Mahaweli Ganga River basin, Sri Lanka, the Sungai Langat River basin, Malaysia, the Tana River basin, Kenya and the Lerma-ChapalaSantiago River basin in Mexico.

This review indicated that introduction of new RBOs tasked with IWRM does not always run smoothly in many countries. Widespread uncertainty has been identified regarding the role and functions of RBOs, specifically concerning the implementation of the IWRM. It found that there was a difference between the objectives and actual activities of the RBOs which appeared to be related to the limited human, financial and institutional capacity as well as inadequate resources of the organisation. As a result, this review indicated that water quality issues had not received the attention that they should.

A recommendation arising out of the review is that performance indicators need to be formulated for RBOs.

Morocco - National level: In terms of the management of scarce water resources and pilots on pollution control, Morocco is faced with a combination of scarce water resources and a rapid population increase. This has led to an increase in water pollution.

Master Plans of Integrated Water Resource Development were put in place by the Ministry of Land, Water and Environment in 2001, and this was followed by the implementation of the National Water Plan, administered through the Ministry of Land, Water and Environment, in 2006. The National Water Plan gave effect to improvement of institutions and policies for water resource management following IWRM principles. It also created the opportunity for increased involvement in water resource management by non-governmental. In particular, pilot projects were undertaken within the wastewater industry which has led to the construction of innovative wastewater treatment plants.

The Soussa -Massa River Basin Agency has been established, and this has enabled multi- agency cooperation and participation of private water user associations in management decisions. In addition, procedures for allocation of water have been established together with technical capacities to allocate and monitor water quantity and quality. The mechanism for communication between sectors and agencies has been also established.

The activity around water resource management has also led to a significant reduction in soil loss in the Watershed through 
the implementation of improved soil conservation measures (USAID Water Team, 2001).

Malaysia - Local level: Rehabilitation of Lakes in Kelana Jaya Municipal Park. Lakes in the Kelana Jaya Municipal Park in Malaysia had become polluted over the years through mining and municipal activities. Tin mining in the catchment had caused serious pollution, and more recently rapid urban development had added wastewater, solid waste and storm water overflow to the lakes. The lakes were used for fishing and recreation, but the pollution had changed the lake ecosystem completely, causing loss of wetland plants, poor water quality and loss of animal life. Local residents decided to take action, and a stakeholder forum of 400 Friends of Kelana Jaya Park formed with a 15-member Steering Committee. The first activity was to initiate an awareness programme.

This programme was introduced into three schools with the target audience being students, parents and teachers. Communities and local authorities were brought together and identified and implemented actions integrating urban and environment planning. This action led to substantial improvement in the water quality of the lake. Solid waste and discharge from the storm water drains was reduced by $60 \%$ and the quality of discharge from oxidation ponds improved as a result of refurbishment of the ponds stimulated through this project.

The water quality in the lake improved with the resultant improvement in both the fisheries and health of the lakeside community (GWP IWRM ToolBox).

Pacific Small Island Developing States (SIDS): Integrating coastal and water management - Local approaches to IWRM have been practiced in the Pacific SIDS for centuries by local communities through traditional coastal, land and water resource management measures which have sustained islands' resources for hundreds of years. But conditions have changed: rapid population growth, increasing urbanisation, damage to catchments resulting from deforestation, poor waste management practices leading to water pollution, and climate change posing serious challenges to Pacific SIDS. The productive fisheries of the ecosystems that support the economies of nations, islands and communities are critically threatened with up to $50 \%$ of the region's total biodiversity at risk.

Within a regional framework the Global Environment Facility (GEF) through UNDP, UNEP and the Pacific Islands Applied Geoscience Commission (SOPAC) have developed integrated coastal and watershed management and sustainable IWRM projects in the region to address these challenges and achieve sustainable management of the islands water, coastal and ocean resources.

Results so far include the establishment of National Coordinators and National Task Forces that meet regularly to ensure effective coordination; improved technical capacity in environmental protection activities; increased public awareness and participation in waste reduction and local resource management; improved marine habitats; waste management systems including composting and recycling which have reduced water pollution; new water resource bills in some countries. In Lepa and Apolima Islands, Samoa freshwater management plans have been developed and the project has also led to a decrease in landbased pollution and a reduction in waste (Global Environment Facility - International Waters Programme, 2007).

In South Africa the enabling environment for IWRM is established through both legislation and Presidential proclamation.
Chapter 3 of the National Water Act (Act 36 of 1998) (NWA) provides for both basic human needs and the protection of ecological processes through the provision of a resource classification system in which the environmental water quality and quantity of a water resource is determined and then managed at the determined level. A part of the classification system is the provision of an ecological reserve which is designed to maintain ecosystem resilience as well as the support of socio-economic activities at a predetermined level. The NWA also makes provision for pollution prevention and remediation. In addition, the National Environmental Management Act (Act 107 of 1998) (NEMA) and a suite of accompanying legislation such as the Biodiversity Act (Act 10 of 2004) is in place to ensure that ecological integrity of systems is preserved. A strength identified in Uganda is that water and the environment are managed by the same department, leading to congruity in legislation. This is not the case in South Africa although the President has instructed government departments to work together in a system of co-operative governance. Institutional arrangements arising from the legislation have meant that the resource classification system has been developed, and the Reserve has been given legal status as a nonnegotiable allocation of the resource. The Reserve comprises two parts, one being the Basic Human Needs Reserve to ensure that people reliant directly on the resource have water and the other being the Ecological Reserve. The first CMA has been established and others will follow soon. This has led to action being taken on several environmental issues.

National monitoring programmes have been implemented and environmental flows are in the process of being implemented in many of the country's catchments. Water quality will be addressed through explicit actions to control pollution. However, although water management has been devolved to catchment level, it has yet to be integrated with local government.

\section{Discussion}

The environment is essential for sustainable water use and IWRM places the ecosystem within the framework of water management. It considers the value of functions of the environment for sustainable water management. In this paper a number of cases were presented that demonstrate that IWRM works under the right conditions and given the time to have an impact.

The case studies presented above cover a variety conditions. For example, the rehabilitation of lakes in the Kelana Jaya Municipal Park in Malaysia was a relatively small project involving a relatively small number of people who were committed to the project and aligned with a common vision from the start. It was initiated by people who lived around and used the lakes, not by a government agency. This bottom-up approach showed positive results fairly quickly, and the people who were involved were able to reap positive benefits from their endeavours.

The South African example, though, involves the entire country and is being driven by national government. It is a top-down approach dealing with many organisations and people, and for many of whom the process is not central to their interests. Thus, implementation of IWRM principles now has to gain the support of people many of whom are not particularly concerned with environmental sustainability. The result of this is that it is necessary, through a process of capacity building, to align people in the common vision of IWRM, including sustainable environmental management, and this process is taking time. Taking an IWRM approach, thus, becomes more complex in more extensive situations and requires strong institutional support if it is to be successful. 
This begs the questions 'what is an acceptable lag time between the decision and tangible impacts of applying an IWRM approach?' and 'what measures can be put in place to shorten this lag time?' If the process continues for too long with no apparent progress, people will become disillusioned and revert to the management methods used in the past. This means, ideally, that the change towards IWRM, with the alignment of stakeholders with the common vision, should be managed in a manner in which people are able to see the progress made. Immediate action during the process helps keep up the momentum (CapNet, 2005). The process should have firm institutional and political commitment, and should be implemented in as short a time as is practical.

\section{Conclusion}

Following the International Conference on Water and Environment (Dublin, 26 - 31 January, 1992), the IWRM concepts have been around and further developed for the past 16 years. In many countries it has changed existing water management structures and practices dramatically and many have engaged in a long process of planning and institutional reform. Some countries have found it an opportune moment to change or update their water laws to create an environment in which water could be managed in an integrated manner. A GWP survey in 2006 showed that two-thirds of the countries are at some stage of introducing IWRM as a guiding principle for water management (GWP, 2006). In a recent follow-up survey conducted by UNWater it was concluded that there has been some improvement in the IWRM planning process at national level in developing countries but much more needs to be done to implement the plans. Of the 53 countries for which comparison was made between the GWP and the UN-Water surveys the percentage of countries having plans completed or under implementation has risen from $21 \%$ to $38 \%$. On this measure the Americas have improved most - from $7 \%$ to $43 \%$; the comparable changes for Africa were from 25\% to $38 \%$ and for Asia from 27\% to 33\% (UN-Water, 2008).

As this paper has argued, where the process has been topdown and stakeholder engagement has come as an afterthought, the institutional and legal changes have had little effect on the way water and water use are being managed where it matters most, at the basin and community level, and tangible benefits for water quality and ecosystems are scarce. However, with proof of many examples at basin level the paper also showed that IWRM works when the process is being driven by local interests and addresses real needs for water use sectors, e.g. agriculture, water supply or the environment.

The presented cases have shown that management instruments are generally available and that enabling factors (legal reform) are more developed than institutional arrangements for IWRM. Some countries have created independent agencies responsible for water management, others have started setting up river basin organisations through which management and participation will be organised. However, the roles and functions of such organisations are not always clear, often also not to the stakeholders involved (Cap-Net, 2008). There is an obvious need for development of trans-disciplinary understanding of the concepts and principles that IWRM is a means and not an end in itself - it is about people's behaviour. The management of the way in which water is being used is more effective than trying to manage the resource. Pollution control, monitoring and compliance are considerably improved through involvement of the stakeholders.
There is a clear and identified need to develop water management capacities at all levels (local, political, management). Indicators to monitor and evaluate progress in water management practices following capacity development initiatives need to be developed. Above all, awareness of stakeholders needs to be raised and active participation organised and enhanced.

Through changes in water management towards IWRM, the environment has been given a voice that it didn't have previously. Before applying IWRM principles, the environment was hardly considered in sectoral water management practices and decision making. This is a considerable gain and it becomes more apparent in small-scale projects and at local level where the IWRM approach is applied. The challenge is to keep up the momentum, deliver tangible benefits and develop the capacity needed to drive and manage change.

\section{References}

BELCHER T (2008) Water Resources Management Instruments in IWRM: Addressing Water Environmental Needs in South Africa. Proc. Int. Conf. IWRM. 10-12 March 2008, Cape-Town, South Africa.)

BEELER S (2006) Common Pool Resource Management in the Niger Inland Delta of Mali: Strategies and Potentials for Conflict Mitigation. Building the European Commons: from Open Fields to Open Source. IASCP Europe Regional Meeting, 23-25 March, Brescia, Italy. - <http://www.eco.unibs.it/ iascpeu/papers/Beeler.pdf $>$

CAP-NET (2003) Tutorial on Integrated Water Resources Management. Delft, the Netherlands. $<$ http://www.archive.cap-net.org/iwrm_tuto$\mathrm{rial} / \mathrm{mainmenu} . \mathrm{htm}>$

CAP-NET (2005) Integrated Water Management Plans: Training Manual and Operational Guide. Delft, the Netherlands. <http://www. cap-net.org/sites/cap-net.org/files/English\%20version.pdf>

CAP-NET (2008) Performance and Capacity of River Basin Organisations. Cap-Net, Pretoria, South Africa.

COSTANZA R, D'ARGE R, DE GROOT R, FARBER S, GRASS M, HANNON B, LIMBURG K, NAEEM S, O'NEILL RV, PARUELO J, GASKIN RG, SUTTON P, and VAN DEN BELT M (1997) The value of the world's ecosystem services and natural capital. In: Nature 387.

EU Liaoning Integrated Environmental Program (2008) Chief of EU Party Alan Edwards - MWH Environmental Engineering.

GLOBAL ENVIRONMENT FACILITY - INTERNATIONAL WATERS PROGRAMME (2007) Delivering Results: Implementation of the Strategic Action Programme of the Pacific Small Islands Developing States (SIDS) and Integrated Water Resources Management in Pacific Island Countries: A Synopsis. GWP Consultants. SOPAC. $<$ http://www.sprep.org/iwp/index.htm>

GWP IWRM ToolBox, Case \# 173 - www.gwptoolbox.org

GWP (2006) Setting the stage for change; second informal survey by the GWP network giving the status of the 2005 WSSD target on national integrated water resources management and water efficiency plans. Stockholm, Sweden.

GWP Technical Committee (2006) Water and Sustainable Development: Lessons from Chile. Policy brief prepared by Sandy Williams and Sarah Carriger

IUCN (2000) Vision for Water and Nature. A world strategy for conservation and sustainable management of water resources in the 21st century. Gland, Switzerland, 52 pp. <www.iucn.org/webfiles/doc/ WWRP/Publications/Vision/VisionWaterNature.pdf >

MILLENNIUM ECOSYSTEM ASSESSMENT (2005) Ecosystems and Human Well-Being. Island Press, Washington, DC.

NIKOLAYENKO AY and KENSHIMOV AK (2008)The Plan of Integrated Management of Water Resources of the Republic of Kazakhstan.

POLLARD S and COUSINS T (2008) Towards Integrating Community-Based Governance of Water Resources with the Statutory Frameworks for Integrated Water Resources Management. Report No TT 328/08. Water Research Commission, Pretoria, South Africa 
PUNGWE RIVER BASIN JOINT INTEGRATED WATER RESOURCES MANAGEMENT STRATEGY. Site visited 03-2008. $<$ Www.pungweriver.net $>$

SOLANES $M$ and GONZALEZ-VILLARREAL F (1999) The Dublin Principles for Water as Reflected in a Comparative Assessment of Institutional and Legal Arrangements for Integrated Water Resources Management. GWP TEC paper 3. Stockholm, Sweden. $<$ http://www.gwpforum.org/gwp/library/TAC3.PDF $>$

TINDIMUGAYA C (2008) Enabling Factors: Legislation, Policies in
Water Management and How They Address the Environment.Proc. Int. Conf. IWRM. 10-12 March, Cape-Town, South Africa.

UN-Water (2008) Status Report on IWRM and Water Efficiency Plans for CSD16. http://www.unwater.org

USAID Water Team (2001) Case Study in Integrated Water Resources Management. USAID Morocco SO2 Close-Out Report.

ZAKARIA S (2008) Case study: Management Instruments for Langat River Basin Proc. Int. Conf. IWRM. 10-12 March, Cape Town, South Africa. 